\title{
NOBRES E ANJOS, 45 ANOS DEPOIS: GILBERTO VELHO E A ANTROPOLOGIA DE URBANAS SENSIBILIDADES
}

\author{
Raphael Bispo ${ }^{1}$ e Oswaldo Zampiroli ${ }^{2}$ \\ ${ }^{1}$ Universidade Federal de Juiz de Fora, Juiz de Fora, MG, Brasil \\ ${ }^{2}$ Universidade Federal do Rio de Janeiro, Rio de Janeiro, RJ, Brasil
}

\section{Apresentação}

Zona Sul do Rio de Janeiro, bairro do Jardim Botânico, início dos anos 1970. Amigos que estão "sentindo falta" uns dos outros decidem fazer reunião em apartamento. A vitrola é ligada e grupos se formam pelos cômodos a conversar. A música pop americana predomina, mas canções de Caetano, Gil e Gal têm lugar cativo nas fitas-cassetes preparadas para a ocasião. Muitos convidados levam bebidas, garrafas de uísque e de vinho são servidas sem parcimônia. Alguns não desejam ingerir álcool, mas não negam os cigarros de maconha que começam a circular pelo local, inicialmente de maneira mais reservada em um quarto, depois de modo mais explícito nos espaços centrais e devassados do apartamento. Teme-se o perigo que pode gerar a disseminação do forte cheiro da substância pelo prédio, afinal, vivia-se uma ditadura militar no Brasil, e o temor da denúncia era recorrente. Quase todos os presentes dão uma "bicada". Enquanto isso, alguns casais de namorados "não estão bem" e paqueras eclodem aqui e ali pelos escuros corredores. As "pequenas infidelidades" servirão de combustível para várias conversações entre as pessoas durante dias após o encontro seja na praia de Ipanema, seja em um sítio em Petrópolis - até que novos fatos sobre suas vidas privadas desbanquem tais pautas. A festa acaba às 4 da manhã com todos os amigos voltando para suas respectivas casas.

A pequena vinheta etnográfica soa aparentemente despretensiosa a muitos leitores numa rápida abordagem. Certamente, por conta da proximidade que a descrição de um encontro entre amigos pode suscitar em uma geração de pesquisadores afeita não só a observar esse tipo específico de "familiar", mas também por ter sido gestada numa tradição disciplinar brasileira que nunca reduziu o fazer antropológico ao estudo das popula- 
ções tradicionais. Entretanto, esta mesma cena pode ser situada em um contexto mais amplo, aquele no qual conseguimos observar como certas formas de pensar antropologicamente o urbano se erigiram nas pesquisas no Brasil principalmente a partir dos anos 1970. Por meio desta outra perspectiva, é possível captar a complexa trama etnográfica tecida pelo então jovem antropólogo Gilberto Velho (1945-2012) em Nobres e Anjos: um estudo de tóxicos e hierarquia, sua tese de doutoramento defendida em 1975, mas publicada com pequenas alterações apenas em 1998. Em meio a passeios a sítios da família, lanches em sorveterias e confraternizações nos aniversários de amigos, constatamos na obra o alvorecer de um importante momento do pensamento antropológico brasileiro.

É com tal espírito que este ensaio bibliográfico se desenvolve ao retomar uma obra que há quarenta e cinco anos vem servindo de inspiração a inúmeros antropólogos: num primeiro plano, relembrar e situar as vivências de efervescentes juventudes que encontraram suas formas de estar na cidade associadas às satisfações subjetivas geradas pelo uso de drogas nas franjas de um regime autoritário no início dos anos 1970. Por outro lado, refletir sobre a maneira pela qual esse campo plural da antropologia urbana tem se constituído na prática e teoricamente entre nós, considerando a obra de Gilberto Velho como referência central para a afirmação de um modo específico de estudo das cidades nas teorias sociais brasileiras.

Este ensaio bibliográfico está estruturado em três partes: na primeira, contextualizaremos histórica e teoricamente Nobres e Anjos, buscando destacar a dupla temporalidade que marca esta obra, ou seja, seus momentos de escrita e defesa em 1975 e o de publicação em 1998; na segunda parte, a fim de melhor entendermos a etnografia de Velho, acompanharemos as construções subjetivas da juventude contracultural da década de 1970 por meio dos debates sobre classe social e comportamento desviante que são tecidos na obra em tela; por fim, na última parte do ensaio, realçaremos a originalidade da contribuição de Velho tendo em vista o contraste que o autor estabelece na antropologia dedicada ao estudo das cidades até então feita no Brasil. A grande ênfase em seus escritos às dimensões emocionais que integram a vida social citadina e dão sentido às experiências de seus interlocutores será aqui nomeada de antropologia de urbanas sensibilidades. ${ }^{1}$

\section{Contexto histórico e teórico da obra}

Nobres e Anjos se arquiteta a partir de um objetivo de pesquisa claro: dentre as idas e vindas de seus encontros com dois diferentes grupos de jovens 
de camadas médias moradores das áreas nobres do Rio de Janeiro, era pretensão de Velho comparar seus "estilos de vida" e "visões de mundo" - seguindo as terminologias fenomenológicas das interpretações simbólicas de Clifford Geertz - particularmente suas relações com o consumo de substâncias ilícitas, os chamados "tóxicos". A pesquisa de campo ocorreu entre meados de 1972 e 1974, sendo o texto final do trabalho defendido como tese de doutorado em ciências humanas no ano de 1975, sob a orientação de Ruth Corrêa Leite Cardoso na Universidade de São Paulo (USP).

Eram os nobres os jovens adultos de 25 a 35 anos de idade com os quais Velho conviveu para desenvolver sua etnografia. Envolvidos com cinema, teatro, literatura, entre outras artes, vários abandonaram empregos fixos "caretas", "pequeno-burgueses", a fim de fazer da atividade artística algo para além de um hobby. Interessados nas "boas coisas da vida" - e acusados várias vezes de "gastarem mais do que ganham" - tinham um alto padrão de consumo e viagens, demonstrando uma situação financeira variável e dependente de suas redes de parentesco, mesmo sendo críticos dos pais e de seus modelos de vida, vistos como infelizes em seus casamentos ou defensores de rígidos processos educativos para os filhos. As drogas e a psicanálise caminhavam juntas na compreensão das transformações existenciais dessas pessoas. Descobrir "seu tóxico" e "seu analista" era uma forma de "autoconhecimento", parte essencial da constituição de si no grupo e da busca por sua "autenticidade". Maconha, cocaína, ácido, ópio, haxixe e remédios controlados como Mandrix², hoje fora de circulação, foram utilizados das maneiras mais variadas por esses jovens.

Porém, essa conexão afetiva gerada por tal consumo não apagava o clima de competição e rivalidade no grupo em termos de inteligência, beleza e sucesso profissional. A defesa da igualdade de gênero e de liberdade entre cônjuges em nada impedia diversos momentos de discriminação a mulheres "infiéis", por exemplo. Vários desses jovens foram "de esquerda" ou "comunistas" no passado, geralmente nos anos 1960. Estas experiências eram por eles ridicularizadas durante a pesquisa de campo, apesar de se apresentarem como progressistas, inovadores, "vanguardistas". Diziam-se "desiludidos" com a participação política, mesmo sendo a maioria de críticos do regime militar. "Comunista, fascista, marxista, liberal, sei lá. Essas coisas hoje em dia não me interessam, não me emocionam. Estou preocupado em me conhecer, sem subterfúgios e facilidades. Para isso, os chamados tóxicos têm me ajudado, assim como a análise" (Velho 1998:110), resume um dos nobres em entrevista.

Já os anjos eram uma geração bem mais nova, entre 15 e 20 anos, ainda nos períodos secundaristas do ensino, todos alunos de colégios de 
elite. Frequentadores de uma conhecida lanchonete de Ipanema, era ali que estabeleciam seus laços de sociabilidade, ${ }^{3}$ usando roupas "básicas e leves" - jeans, camisa de malha, havaianas - visto o ar esportivo por conta do envolvimento com o surf. Havia entre eles um apelo ao culto do corpo, devido à dimensão estética e erótica presentes em suas interações. "Queimados de sol", ouviam rock e pop internacional, não demonstrando maiores interesses por cinema ou literatura erudita, já que eram muito afeitos à cultura de massa. Críticos dos militares por sua "caretice" e "rigidez", em nada se envolviam com a política em geral, achando "chatos" os debates sobre esquerda, comunismo, entre outros temas "sérios".

Prezando um forte discurso de escolha e liberdade, o consumo de maconha e em menor escala de cocaína e Mandrix servia ao grupo na busca por sensações agradáveis, "curtição", porém sem maiores elaborações existenciais sobre os efeitos dessas substâncias em seus cotidianos, tal como faziam os "aristocráticos" nobres. Em termos afetivo-sexuais, colocavam-se veementemente contrários à "caretice" da monogamia, do casamento e do "heterossexualismo ortodoxo". A informalidade de suas vidas dava uma sensação de "eternas férias" aos seus críticos familiares, visto o pouco controle de horários, a desvalorização dos estudos e a falta de preocupações com futuras atividades profissionais. "O seu mundo é basicamente do esporte, da música. É lúdico, festivo e erotizado", resume Velho (1998:160).

São recorrentes no meio acadêmico as memórias coletivas em torno das razões para não se publicar imediatamente Nobres e Anjos em formato de livro. Velho vinha cada vez mais adquirindo prestígio acadêmico no início dos anos 1970 como professor do Museu Nacional, tendo sua dissertação de mestrado, A Utopia Urbana, editada em 1973. Logo, esperava-se também que sua tese de doutorado chegasse rapidamente às livrarias. Entretanto, o recrudescimento da repressão na ditadura militar brasileira em 1968, após o Ato-Institucional Número 5 (AI-5), tornava a temática da obra um alvo certo para possíveis perseguições a "subversivos". Tanto o autor quanto aqueles que ele retratava poderiam ser enquadrados na categoria, mesmo que os nomes não fossem revelados e todos fizessem parte de segmentos da elite. O fato de pertencerem a famílias com certo grau de prestígio social, em muitos casos, evitou que essa juventude sofresse represálias mais ofensivas das forças policiais devido ao porte de drogas, revelam os dados etnográficos (Velho 1998:164). Porém, a necessária prudência nos anos de chumbo fez o pesquisador retardar a publicação "ampla e irrestrita" de sua tese.

Além desse temor político, existia o receio de Velho em ferir as suscetibilidades de seus "informantes" com a publicação do texto (Velho 1998, 2012). Isto porque o trabalho seguia a tônica muito cara às suas típicas inquietações 
intelectuais: a de produzir conhecimento sobre a diferença alicerçado na observação direta de seu próprio cotidiano, expressão máxima do at home, um olhar científico que não separava muito "o palco do backstage" (Peirano 2012:7). Muitos dos jovens da pesquisa eram conhecidos de longa data. "Conheço várias das pessoas há muito anos, sou amigo de alguns e, sem dúvida, representam parte considerável do meu círculo de relações" (Velho 1998:182).

Essa proximidade afetiva sempre renderia a Velho inúmeras reflexões metodológicas ao longo de sua carreira em torno das "dificuldades de isenção", de o quanto seus pontos de vista se "confundem" ou não com os de seus "nativos" (:67) e mesmo os limites do que nos é ou não "familiar", dada a proximidade "físico-social", mas não "psicológica", que temos com certos temas que nos soam aparentemente conhecidos (Velho 1978). "Que tipo de trabalho é possível nestas condições? Quão confiável é o tipo de conhecimento obtido dentro deste quadro?" (Velho 1980:17). ${ }^{4}$ Optou-se por fazer uma circulação restrita do texto diante do temor de gerar animosidades com pessoas conhecidas, trazendo à tona episódios recentes de suas rotinas, decorrentes das implicações metodológicas desses primeiros estudos sobre as "alteridades próximas" (Peirano 2006:61). Cópias informais difundiram-se de maneira circunscrita pelo meio acadêmico e a tese podia ser consultada diretamente nas bibliotecas da USP e do Museu, apenas. ${ }^{5}$

Ora, como uma obra que ganha circulação editorial de peso vinte e três anos após a sua confecção pode ser considerada um marco importante do pensamento antropológico? O contraste com o já mencionado A Utopia Urbana, disponível nos mercados editoriais três anos após a sua defesa em 1970, pode ser interessante para nós. Nesta última obra vemos um jovem antropólogo andando em um "terreno movediço" (O' Donnell 2013:3) que seria o do ainda incipiente campo da antropologia urbana, com escassas referências bibliográficas e suportes teóricos sobre o tema, mas trazendo metodologicamente uma abordagem pouco usual para a disciplina, a etnografia de um prédio de conjugados em Copacabana.

Em Nobres e Anjos tais limitações enfrentadas pelo autor em sua dissertação não se fazem presentes. Observamos Velho se apoiando reflexivamente nas tradições bibliográficas que carregaria posteriormente consigo ao longo da carreira, visto ser ele um pesquisador, como defende Duarte (2012a), muito afeito a valorizar um conjunto de autores, de categorias de análise e de instrumentos de observação bastante precisos, capazes de dar aos seus escritos uma marca autoral. Howard S. Becker, Erving Goffman e o interacionismo simbólico fazem-se presentes na obra, por exemplo, descrevendo os "desvios" de jovens nas aprendizagens de técnicas de consumo de drogas, além de emergirem no texto importantes autores que desenvolveram pesquisas sobre 
delinquência juvenil no âmbito da Escola de Chicago, como Albert Cohen e Frederic Trasher. Conjugadas a essa base da sociologia, as tradições antropológicas também servem a Velho para a construção de sua argumentação: como dito, a antropologia simbólica norte-americana de Clifford Geertz, fortemente inspirada na fenomenologia de Alfred Schutz; a recuperação de autores norte-americanos mais antigos em novas releituras teóricas, como Gregory Bateson; e as preocupações pós-funcionalistas dos ingleses da chamada Escola de Manchester e suas inquietações com a forma de definir determinados tipos de relações sociais mais porosas, instáveis, não facilmente categorizáveis em conceitos como "grupo", "roda" ou "rede" (Clyde Mitchell, Elisabeth Bott, entre outros). Por fim, cabe mencionar os autores nacionais citados, importantes para a hegemônica cena intelectual do Pensamento Social Brasileiro, que fornecia a Velho a possibilidade de "interpretar" seu país dominado há pelo menos dez anos por um regime ditatorial, tendo as vivências de seus interlocutores de camadas médias em foco, tal como os carnavais de Roberto DaMatta (a quem o autor agradece no início do texto, seu amigo do PPGAS) e o mandonismo local de Maria Isaura Pereira Queiróz.

Nas memórias de Velho, essa consolidação de um cabedal teórico-metodológico preciso liga-se a uma temporada de estudos e pesquisa nos Estados Unidos no ano de 1971, quando lá foi realizar uma especialização em antropologia urbana e sociedades complexas no Departamento de Antropologia da Universidade do Texas, em Austin, com passagens por Boston. Retrospectivamente, dizia que nessa viagem paradigmática - uma típica narrativa sobre aperfeiçoamento pessoal em processos de bildung - foi apresentado de maneira mais densa à série de pensadores ligados à Escola de Chicago, particularmente aos estudos de Howard S. Becker sobre marijuana, sociólogo com quem manteria uma amizade de anos, alimentada pela intensa troca de cartas (Velho 2005, 2011; Vianna, Kuschnir \& Castro 2013) ${ }^{6}$ Cabe destacar também que esse viés analítico tem a influência de seus professores norte-americanos Anthony Leeds ${ }^{7}$ e Shelton Davis ${ }^{8}$ em seus cursos no recém-inaugurado PPGAS do Museu Nacional, quando Velho ali realizou seu mestrado no final dos anos 1960.

Assim, Nobres e Anjos é a clara convergência no contexto de uma trajetória intelectual de uma série de estudos e abordagens sobre a cidade que tem em A utopia Urbana, como diz O'Donnell (2013), sua "fundação". Na tese de doutorado, porém, Velho leva à frente e de maneira muito mais complexa um projeto que ele já anunciava nas primeiras linhas de seu clássico de 1973: "Pretendo, com este livro, dar início a uma série de trabalhos sobre o meio urbano, com uma abordagem antropológica" (Velho 1973:1). A "missão" de enveredar-se pelas urbanidades brasileiras, particularmente 
as cariocas, ganhava assim um capítulo importante no percurso de Velho como fundador de um campo de conhecimento. A confluência de diferentes escolas e tradições, naquele momento em seus escritos, tratava-se, nas suas palavras, de seu "coquetel particular" (Velho 2011:168).

É preciso ainda destacar que essa originalidade não se faz apenas pela costura teórica tecida por Velho às perguntas geradas por uma pesquisa de campo pouco comum no período. Faz-se importante também constatar a maneira como sua antropologia dialogava e afastava-se das típicas pesquisas dos anos 1960 e 1970 que tinham como foco as cidades brasileiras, particularmente São Paulo, favorecendo o desenvolvimento daquilo que melhor nomearemos adiante de antropologia de urbanas sensibilidades por conta desse contraste com o establishment do período.

Importantes autoras como Eunice Ribeiro Durham e a própria orientadora da tese de Velho, Ruth Cardoso, dedicavam-se a pensar as experiências de vida nas cidades a partir da chegada de diferentes fluxos de migração de populações vindas das áreas rurais, refletindo sobre a "mudança social" gerada pela "modernização" brasileira e a formação da marginalidade e de áreas pobres e periféricas nas metrópoles (Cardoso 2011a; Durham 1984). Essa abordagem tinha marcas da tradição empírica deixada pelo funcionalismo dos estudos de comunidade da Escola Livre de Sociologia e Política (ELSP) e que teve papel preponderante nas ciências sociais brasileiras, particularmente nas paulistanas, entre as décadas de 1930 e $1970 .{ }^{9}$ Entretanto, ambas as autoras demonstravam estar afastadas de algumas das típicas proposições que eram a tônica desses estudos em seus áureos tempos, como a problemática da "aculturação" e da "integração" de certos grupos étnico-raciais (negros, japoneses, alemães, entre outros) à "sociedade abrangente" (Magnani 2012; Dutra \& Ribeiro 2013).

Conjugando a essa formação a "sociologia crítica" marxista da Faculdade de Filosofia e Ciências Humanas (FFLCH) da USP, sob a forte influência de Florestan Fernandes ${ }^{10}$, tanto Durham quanto Cardoso são figuras-chave também para se compreender a emergência de uma antropologia urbana no Brasil. ${ }^{11}$ Elas observavam as cidades como um fenômeno em constante mudança, tentando captar as modificações e as permanências geradas por "um processo de integração de contingentes populacionais crescentes a um sistema capitalista-industrial" (Durham 1984:19). Entendia-se assim o espaço urbano como um "contexto" que gerava transformações socioculturais e modificava a vida de seus moradores, sobretudo os mais pobres. ${ }^{12}$ Durham atentaria durante anos para as permanências e as transformações nos laços familiares de migrantes do interior do estado de São Paulo que chegavam à capital, particularmente 
italianos (Durham 1984, 2004); Cardoso estudaria a migração japonesa das áreas rurais para o centro paulistano, além de desenvolver pesquisas subsequentes sobre moradores de favelas (Cardoso 2011a, 2011b).

A marca de Velho em Nobres e Anjos, portanto, não está em ser necessariamente o "primeiro"13 a descortinar a vida urbana por meio de um olhar antropológico, mas sim na consolidação de um arcabouço teórico diferenciado, articulado com inquietações metodológicas, que lhe garantiu um modo de "observar o familiar" e formular objetos próprios de pesquisa. Se é sempre difícil situar as inspirações teóricas de um autor, talvez seja mais pertinente perceber seus afastamentos. Velho deixava de lado o arsenal teórico recorrente nas ciências sociais da década de 1960 que conciliava o empirismo funcionalista com um corte europeu de macroanálises e com tintas marxistas a fim de refletir sobre o fenômeno urbano, além de um projeto estruturalista que cada vez mais ganhava relevo acadêmico, particularmente na etnologia (Viveiros de Castro 1999). Não se tratava também de um uso inédito da Escola de Chicago (vide as marcas dessa plural Escola nos estudos de comunidade de que Velho se afastava, por exemplo), mas de uma apropriação de certas correntes específicas oriundas dessa vertente norte-americana da sociologia, particularmente do interacionismo simbólico, a "terceira geração" de estudiosos da Escola (Becker 1996).

Juntam-se a isso autores alemães como Georg Simmel, interlocutor privilegiado de muitos autores de Chicago, além de uma combinação entre a fenomenologia filosófica inspiradora das teorias antropológicas norte-americanas hegemônicas no período com o pós-funcionalismo inglês dedicado às "sociedades complexas". Não são à toa as constantes reclamações de Velho em suas memórias acerca do "nacionalismo anti-imperialista" do meio intelectual durante o regime militar e a rejeição aos autores estadunidenses, nomes estes acusados pelo establishment marxista de serem "empiricistas" e sem "sofisticação", pouco preocupados com os "processos sócio-históricos" (Velho 2005:37-38). Logo, a antropologia urbana que nasce em Nobres e Anjos promove um "retorno" à rarefeita cena antropológica sobre a cidade de tradições de estudo deixadas de lado à época, particularmente a norte-americana, possibilitando uma análise mais apurada das políticas do cotidiano do espaço urbano.

Dito isso, cabe ressaltar que Nobres e Anjos é uma obra marcada simbolicamente por uma dupla temporalidade, ou seja, por sua defesa enquanto tese de doutorado há quarenta e cinco anos atrás e pelo fato de ter apenas chegado ao mercado editorial há exatos vinte e dois anos. Portanto, é uma produção acadêmica de 1975, publicada em 1998. No final dos anos 1990, com uma trajetória acadêmica já bastante consolidada, inevitavelmente a decisão de 
Velho em finalmente lançar a obra ganhava um tom memorialístico, isto é, tinha o propósito de jogar luz em antigos manuscritos de um agora canônico autor. "Algumas editoras regularmente demonstravam interesse pela sua publicação. Passei alguns anos sem relê-la na íntegra. Finalmente, instado por amigos, tirei-a da estante e fiz leitura atenta, chegando à conclusão de que valia a pena publicá-la sem alterar o texto original" (Velho 1998:8).

A iniciativa, assim, servia ao propósito de legitimar uma trajetória intelectual já prestigiada, explicitando as bases originárias de um percurso acadêmico de sucesso. "Talvez com alguma modéstia, vejo em Nobres e Anjos um papel pioneiro nos estudos antropológicos do meio urbano e da sociedade contemporânea, justificando, por isso também, sua tardia publicação" (:8). Em 1998, Velho já havia chefiado o Departamento de Antropologia do Museu Nacional e se tornado professor titular da instituição; foi presidente da Associação Brasileira de Antropologia (ABA) e da Associação Nacional de Pós-Graduação e Pesquisa em Ciências Sociais (Anpocs), além de atuar na Sociedade Brasileira para o Progresso da Ciência (SBPC), instituição que até então oferecia muito pouco espaço para os cientistas das áreas das humanidades.

Entretanto, seria bastante redutor sintetizar a tardia publicação do livro a apenas uma (auto)exaltação memorialística de um autor ainda em vida. Afinal, que diálogos o texto estabelecia e consolidava naquele momento? A esta altura de sua trajetória, Velho já havia pavimentado teórico-metodologicamente a densa estrada da antropologia urbana aberta por A Utopia Urbana e Nobres e Anjos através de obras que foram burilando conceitualmente e de maneira mais densa, ao longo dos anos 1980 e 1990, aquilo que nos fora apresentado por meio de pesquisas etnográficas realizadas nas décadas anteriores. Importantes livros-coletâneas que reuniam artigos de Velho, como Individualismo e Cultura (1981), Subjetividade e Sociedade (1986) e Projeto e Metamorfose (1994), deram ao público a possibilidade de conhecer, mesmo que de modo um tanto indireto, o conteúdo que fora desenvolvido em Nobres e Anjos, tendo em vista que são trabalhos que captam e organizam muitas das inquietações que o autor trouxera à academia a partir de sua tese de doutorado. Neles, conceitos-chave como os de "campo de possibilidades" e "projetos", bem como suas conhecidas análises sobre a dimensão do individualismo nas experiências de vida nas cidades - de forte inspiração simmeliana - ganharam densidade e serviram de norte analítico para variados trabalhos de orientandos que passaram a se inspirar no novo modelo de antropologia urbana proposto pelo autor.

Como veremos adiante, o tema do desvio - bastante caro à antropologia de Velho - ao final dos anos 1990, permitiu a consolidação de inú- 
meras pesquisas que pensavam os fenômenos ligados às discriminações e aos preconceitos sociais, servindo como um grande "guarda-chuva" para refletir sobre processos de exclusão ligados ao gênero, à orientação sexual, à raça e aos comportamentos moralmente não desejáveis, como a prostituição, o consumo de drogas etc. O lançamento do livro coroava o campo de conhecimento aberto por Velho nas ciências sociais dedicado ao estudo do "mundo psi" por meio de um olhar socioantropológico, observando também as fronteiras da psicanálise e da psiquiatria com as humanidades em geral, entre outras aproximações.

Foram as inúmeras acusações de "doentes mentais" feitas aos interlocutores jovens de Velho em Nobres e Anjos que o motivaram a se enveredar por parcerias como a estabelecida com o psicanalista Sérvulo Figueira em coletâneas como Família, Psicologia e Sociedade (1981) que, relembra Duarte (2012a:7), serviram de sustentação ideológica para a reforma psiquiátrica brasileira. Um grande evento realizado no ano de 1978 no Rio de Janeiro - o I Simpósio Internacional de Psicanálise, Grupos e Instituições - reuniu psicanalistas, psiquiatras e cientistas sociais, tendo Velho como figura-chave na recepção de personalidades emblemáticas da sociologia estadunidense, como Howard S. Becker e Erving Goffman, convocados ao Brasil para contribuir quanto ao papel das ciências sociais na quebra dos estigmas existentes ao redor dos sujeitos considerados desviantes (Velho 2002:10).

Diante disso, nota-se que Nobres e Anjos adquiriu uma importante função simbólica ao ser lançado em 1998: se não trouxe "novas" questões ou teorias porque naquele momento em que chegava às livrarias jogava luz nas preocupações de uma determinada época no início dos anos 1970, a inédita edição servia não só para solidificar a carreira de seu autor, mas também para perpetuar um modelo bastante específico na antropologia brasileira de observação do fenômeno urbano.

\section{Classe e desvio na contracultura}

As experiências contraculturais dos anos 1970 são tão diversas quanto os estilos de vida que delas fazem parte, o que nos permite compreender sentidos os mais variados acerca do uso de drogas por uma juventude que, hoje, em retrospecto, recorrentemente é pensada de forma um tanto homogênea. É provável que isso ocorra porque muitos dos comportamentos dessa geração consagraram-se como o espírito juvenil típico de uma época, verdadeiros "lugares de memória" do que seria ser jovem naqueles anos. Almeida e Eugênio (2007:157) defendem que talvez nem dez por cento da juventude brasileira dos 
anos 1970 tenham aderido de alguma maneira ao universo dos movimentos contraculturais, mas fixou-se na memória coletiva de que ser jovem naquele período era ser algo muito próximo disso que Velho nos mostra na tese.

Ao construir tipos-ideais a fim de contrastar dois diferentes modos de estar na urbe - os nobres e os anjos - o autor parece antever a pertinência histórica de realçar por meio de uma "descrição densa" a pluralidade de estilos juvenis presentes nas camadas médias do Rio de Janeiro. Com isso, aprofundava também suas reflexões sobre tais segmentos da sociedade que foram iniciadas em A Utopia Urbana a partir de seus estratos mais baixos: pessoas que saíam dos bairros periféricos e iam morar em conjugados de Copacabana por enxergarem nesse movimento o acesso a uma "modernidade" que se fazia territorialmente, na área restrita da elite à beira-mar (O'Donnell 2013). Os jovens pesquisados na tese em nada se parecem com os moradores de conjugados, são filhos de famílias já bem consolidadas há décadas nessas localidades, vivendo em boas condições. Não se trata mais, portanto, em termos de narrativas de classe, de histórias de "triunfo" baseadas na premissa da mobilidade social, do "suburbano" que "venceu na vida" e foi morar na zona sul. Velho depara-se com um conjunto de pessoas que, na realidade, a todo tempo, delineia uma distinção perante as outras, ao entrelaçarem suas origens sociais, propriedades, viagens e escolas num discurso de distinção e afirmação de uma superioridade social que se fazia desde o berço.

Assim, o tema da classe social - tão em voga nos anos 1970 - é também central na teoria de Velho. Em Nobres e Anjos, Pierre Bourdieu é um dos autores - ao lado de Max Weber e suas reflexões sobre grupos de status - que permitem a Velho construir suas reflexões sobre a hierarquia entre classes, teórico que tradicionalmente não é tão lembrado assim como uma referência direta de sua obra. É basicamente a partir da leitura de A economia das trocas simbólicas que ele foge de uma observação compartimentada dos segmentos da elite carioca, dando, na verdade, atenção às porosas fronteiras das estratificações que são erigidas pela própria população estudada. Os termos "classes médias", "camadas médias" e, principalmente, "aristocracias dos estratos médios" servem ao autor como uma forma conceitual capaz de matizar os estilos de vida desses segmentos sociais, demonstrando o quanto seus interlocutores desejam não ser apenas "bem-sucedidos" financeiramente, mas "educados", de "bom nível" e dotados de um consumo "sofisticado". Estamos diante, portanto, de uma típica argumentação bourdiesiana sobre as diferentes espécies de capital (econômico, cultural, social etc.) que servem de instrumentos de poder nas estratégias ideológicas das classes dominantes em desacreditar as práticas de outras frações sociais opostas a elas. O gosto dos nobres e 
o dos anjos tornam-se princípios de autoridade. A "luta de classe" se faz também naquilo que consumimos enquanto exercício de ludicidade.

A análise das relações simbólicas de classe foi uma vertente estimulada por Velho em seu particular fazer etnográfico, bastante pertinente para sua antropologia de urbanas sensibilidades. É importante realçar isto porque tal olhar para as camadas médias foi tomado em alguns momentos como uma "abordagem culturalista" por supostamente apagar os conflitos sociais ao dar mais destaque aos valores e estilos de vida constitutivos de um determinado segmento de classe. Na opinião de Durham (1986), por exemplo, inúmeros conceitos como pessoa, indivíduo, individualismo, holismo e ethos vinham nos anos 1970 e 1980 na antropologia urbana sofrendo "deslizes semânticos", visto que muitos pesquisadores evitavam o tratamento direto da problemática social e política neles contida. Para a autora, estes pesquisadores "despolitizam os conceitos com os quais operam, retirando-os da matriz histórica na qual foram gerados e projetando-os no campo a-histórico da cultura" (1986:375). Em relação aos usos do conceito de hierarquia, por exemplo - muito caro à análise de Velho em Nobres e Anjos, estando inclusive no título da tese - na visão de Durham, ele aludiria "menos à organização hierárquica da sociedade do que à presença da hierarquia como valor nas representações coletivas, num claro deslizamento da conceituação sociológica para uma conotação culturalista" (Durham 1986:370). ${ }^{14}$ Apesar dessas pertinentes colocações, acreditamos que as típicas acusações de "culturalista" daquela época às novas abordagens antropológicas da cidade e que pouco dialogavam com as tradições marxistas - como as desenvolvidas por Velho e discípulos não condizem com os dados e as análises presentes em Nobres e Anjos. O debate sobre os conflitos e as tensões de classe emergem em variados momentos da obra, visto que tais tensões são compreendidas pelo autor como algo constitutivo também da circulação típica das metrópoles, da convivência nem um pouco harmoniosa entre "estranhos", os quais acabam entrando em choque. Velho é enfático quando afirma que os postulados do estilo de vida aristocrático e hedonista que descreve operam a partir de um forte poder de exclusão social, em que privilégios de classe servem como atributos para inclusive situações de discriminação racial (Velho 1998:128).

As disputas entre jovens que "não se transam" revelariam essas clivagens, por exemplo. Fechados para o contato com pessoas mais pobres que chegam para a praia nos finais de semana, os frequentadores locais da lanchonete de Ipanema, em vários momentos, discriminam outros fumantes de maconha, a maioria jovens negros da zona norte, vistos como "hippies", "sujos", "ignorantes", "pobres", "suburbanos" e "pessoal além-túnel" (:148-49). 
Alguns nobres também orgulhosamente ridicularizam qualquer tentativa da parte deles de "proximidade com o povo" (:124): "Fui a uns comícios em favela, fui a uns sindicatos. Tentei me forçar a achar legal aquela sujeira, a gostar de samba, frequentei a Estudantina e outras gafieiras. [...] Uma pobreza. Hoje fico até meio envergonhado só de pensar nisso" (:115).

Observamos, então, que não se trata de uma proposta analítica baseada numa mera mensuração de renda, indicando até que ponto certas famílias são de classe alta ou média, por exemplo, delimitando assim suas posições bastante claras numa dada estrutura social. O debate sobre os conflitos sociais se faz etnograficamente presente em Nobres e Anjos a partir das tensões subjetivas de classe que se alicerçam a princípios simbólicos de hierarquização que servem aos processos de construção de imagens de si por parte do grupo investigado. Desse modo, o autor analisa o classismo e até mesmo o racismo desses jovens na produção de suas "fronteiras" subjetivas. O que inquieta o autor, na verdade, são as zonas de tensão e os interditos que se fazem ou são feitos visíveis por esses atores, como as facilidades discursivas da elite branca em expressar desconfortos com pessoas menos abastadas e, de maneira mais velada, negras.

A temática do estudo dos "comportamentos desviantes" é outra vertente analítica da obra e se intersecciona profundamente com a problemática da classe. Se, ao pensar em classe, Velho articula a categoria "hierarquia" para traçar as fronteiras dos grupos que pesquisa, ao lidar com o desvio, ele apresenta as vicissitudes do uso de "tóxicos" para esse mesmo fim. O interacionismo simbólico, sobretudo o clássico Outsider de Becker, salienta os contornos do modo como Velho passa a enxergar a urbe.

Desde a introdução da maconha entre os nobres em 1969 até o início da pesquisa de campo de Velho, o uso das drogas foi mudando e seu significado também. A categoria "viciado", por exemplo, começou a aparecer em conversas e fofocas para designar as tensões subjetivas entre os membros do grupo que passaram a consumir sozinhos alguma substância, fora do contexto comunitário. O uso mais indiscriminado da cocaína também se tornou malvisto. Isto é importante de pôr em relevo, pois nos revela, no âmbito de um comportamento que pode ser visto como desviante, um outro desvio, ou seja, um desvio do desvio. Se o uso dos tóxicos é ponte importante para a formulação da identidade do grupo, assim como recurso para "autoconhecimento", o "exagero" no uso da substância, tanto quanto "dar bandeira", poderia ser enquadrado fora do comportamento permitido.

Deste modo, pensando pelos termos de Becker, Velho demonstra que a categoria "viciado" poderia atribuir aos acusadores o papel de "empreendedores morais", isto é, de produtores de regras na criação de dissidência 
na dissidência. Assim, mesmo que esta designação aparecesse realmente em conversas mais privadas, de poucas pessoas, em contexto de fofoca, ainda havia a possibilidade de que o estabelecimento de fronteiras simbólicas desmantelasse pouco a pouco alianças entre membros do grupo. Velho chegou inclusive a presenciar brigas e amizades desfeitas graças aos problemas do uso do "pó" - fato nunca visto em relação ao consumo da maconha. Ademais, é interessante observar como a atribuição de um comportamento desviante dentro de um comportamento já considerado também desviante está profundamente relacionada à construção de um ideário de classe. "Uma pessoa com poucos recursos que adquire o hábito da cocaína [...] vai deixar de comprar roupas, vai alimentar-se mal [...] Já o indivíduo com alguns recursos poderá consumir cocaína sem grandes exageros, sem deixar de vestir-se bem" (Velho 1998:72), revela um interlocutor de Velho.

O material etnográfico coletado indica que a atribuição do valor pejorativo "viciado" parece estar mais imbricada à maneira com que as pessoas se comportam e se apresentam aos outros ao seu redor do que pela quantidade de substância que é usada. Ao trazer esse matiz para pensar a dinâmica não estanque da produção de subjetividades em uma situação lida como desviante, Velho complexifica a análise interacionista ao somá-la com um marcador social, o de classe, revelando o processo de constante produção de símbolos dentro de uma categoria que poderia ter sido facilmente lida de modo monolítico. Aqui, é possível vislumbrar melhor a convergência teórico-metodológica que orienta o trabalho de Velho: o conceito de "desviante" encontra nas categorias de acusação e também na produção de redes, grupos e identidades seu maior viço.

Assim, os tóxicos seguem sendo um importante mecanismo de produção de identidade e subjetividade para os membros do grupo, tanto em termos coletivos como em termos individuais, mesmo com os jogos acusatórios e os sutis controles morais internos. Isto se dá porque os tóxicos passam a incorporar importantes momentos da vida dos sujeitos, no que diz respeito a um processo de distinção deles diante de seus pais. Pensando a partir dos nobres, por exemplo, o consumo de tóxicos se estabelece na ambiguidade em que, ao passo que valorizam o berço aristocrata onde nasceram, se veem partes de uma contracultura que aspira a romper com a "caretice" dominante. Desta forma, do processo de produção de subjetividades de distinção ("sofisticado", "bem-sucedido", "bom-nível") dentro do mesmo estrato social; da "estranheza" em relação ao passado e aos pais; do paulatino desinteresse por questões políticas ou por questões coletivas, o uso de tóxicos, seja de modo despreocupado, pelos anjos, ou como forma de abertura das sensibilidades individuais, pelos nobres, é interpretado como autonomia e liberdade pessoal. 
O comportamento desviante para Velho, portanto, "só pode ser entendido contextualmente. Mas verifica-se que, na nossa sociedade, de uma maneira ou de outra, ele [o uso dos tóxicos] é um símbolo de diferenciação" (:205).

Voltando novamente à problemática da "hierarquia", é possível vislumbrarmos como Velho, além da classe, também a amarra ao comportamento desviante. Seja em seu efeito positivo ou negativo, o comportamento desviante passa a criar fronteiras entre os grupos e as identidades e pode, assim, tanto estabelecer os limites do que seria o desvio do desvio quanto a classe da classe. Acreditamos que Velho nos apresenta uma modalidade de pensar o desvio de modo não estável, mas em perspectiva e em constante reformulação. O autor destaca os fatores relacionais ressaltados na captura da análise contextual, mas ele o faz relendo a tradição da Escola de Chicago a partir das ambiguidades e dos processos de acusação verificados em seus dados de campo.

Por fim, é possível vislumbrarmos, no contexto, ou nas "políticas do cotidiano" (:209), a união entre uma antropologia urbana do encontro, mais afeita aos escritos de Howard Becker, e uma antropologia urbana dos mal-entendidos, mais próxima dos trabalhos de Erving Goffman. Velho (2008b) apresentou precisamente essa distinção. Se, enquanto para Becker há uma tendência a pensar a interação social pelas possibilidades de sucesso da ação coletiva, em Goffman são mais enfatizados os riscos dos desencontros nestas mesmas interações. E, assim, dessa união, nasce uma análise que perpassa territorialidades, identidades, subjetividades e também sensibilidades que estabelecem uma marca pioneira e dão densidade à epistemologia de Velho.

\section{Por uma antropologia de urbanas sensibilidades}

Qual a pertinência de se pensar em uma antropologia urbana no início da terceira década do século XXI, quando a especialização e a explosão temática marcam a disciplina no cenário científico brasileiro? Vimos aqui que a cena intelectual reunida em torno do rótulo de antropologia urbana refletiu desde os anos 1970 a institucionalização do pensamento antropológico nas universidades, acompanhando também a solidificação de um modelo mais profissionalizante de pós-graduação no país (Bomeny 2015). Construídos cientificamente pelo contraste - nem "campo", nem "floresta" - o "urbano" e a "cidade" surgiram aqui como inquietação analítica quase concomitantemente à própria institucionalização profissional/universitária da etnologia, ramo este muito mais legitimado pelos cânones internacionais. Todo esse 
movimento dedicado ao estudo at home não aconteceu dessa maneira em países fundantes como França, Inglaterra e Estados Unidos, por exemplo, sempre reticentes quanto a esses estilos de pesquisa (Peirano 2006; Cordeiro 2015). Nesse sentido, tornamos a antropologia urbana uma vertente da disciplina e um caso tipicamente brasileiro ao mesmo tempo. ${ }^{15}$

Por isso, fez-se lugar comum ao longo desses anos reflexões sobre as vicissitudes antropológicas do que denominaríamos propriamente de urbano. Parecendo carecer de um objeto próprio, as urbanidades dessa subárea do conhecimento poderiam ser compreendidas como tudo aquilo que ocorre no interior das metrópoles (Oliven 1980). Nessa busca por uma delimitação mais precisa acerca do que é o urbano, os pesquisadores da época envolviam-se em constantes debates. Questionavam-se se no Brasil era feita uma antropologia da cidade, preocupada com situações explicadas a partir de um quadro espacial, "territorialidades"; ou se era uma antropologia na cidade, onde as urbanidades seriam apenas um contexto no qual se desenvolvem vários fenômenos específicos, dentre os quais os antropólogos estariam muito mais interessados nas "identidades" que deles eclodem e não no espaço da cidade propriamente dito (Durham 1986; Magnani 1996).

Parece que não precisamos tanto assim desse distanciamento temporal para suspendermos ou, melhor, matizarmos esse debate. Há quarenta e cinco anos atrás, Velho já nos fornecia pistas a fim de melhor compreendemos como este manancial teórico poderia ser operacionalizado, sem cair facilmente numa reificação da urbe como variante autônoma, mas também sem abrir mão de considerá-la como possível plataforma argumentativa.

Para isso, as linhas de fuga dessa tensão são por ele moduladas com o propósito de destacar analiticamente as "emotividades" de seus interlocutores. Vale lembrar que a epistemologia de Velho é devota dos autores clássicos de início do século XX que, diante do avassalador crescimento das metrópoles europeias, pensaram essas dinâmicas a partir das subjetividades dos citadinos. As interpretações poderiam passear por uma visão mais "negativa" sobre as demandas sensíveis feitas pela cidade tal como a "atitude blasé" simmeliana (Simmel 1976) - quando o homem moderno, encapsulado dentro de si mesmo, impessoal, evita envolvimento com os dramas e as intensidades metropolitanos como forma de proteção psíquica - ou mesmo por um olhar mais positivado sobre o fenômeno, destacando o fascínio gerado pela urbe sintetizado em figuras tais como o flanêur de Benjamin, inspirado em Baudelaire (1995), por exemplo, que sente as pulsões da cidade e com elas gosta de se imiscuir por meio de um caminhar afetado. A essa tradição Velho concilia um olhar fenomenológico para os fenômenos urbanos ao privilegiar os comportamentos e as atitudes das pessoas, "o modo 
pelo qual os eventos são vividos, experimentados pelos sujeitos sociais no fluxo de suas relações" (Duarte 2012b:2). A fenomenologia filosófica de Alfred Schutz e literatos existencialistas como Albert Camus e Jean-Paul Sartre são influências constantemente lembradas e capazes de oferecer um "tom" à epistemologia do autor. ${ }^{16}$

Assim, nota-se que com essas inspirações o autor solidifica no horizonte contemporâneo de estudos da cidade, em nítido contraste com o que era construído nas teorias sociais brasileiras dos anos 1970, aquilo que gostaríamos de nomear de uma antropologia de urbanas sensibilidades. Entendemos as "urbanas sensibilidades" de Velho como uma certa maneira de perceber e compreender os fenômenos da cidade, dando especial atenção ao "espírito" de seus habitantes, constatando a urbe nos processos vitais que a compõem cotidianamente, ou seja, atravessadora de seus modos de subjetivação e existência, não como mero "cenário" das ações desses sujeitos sociais. Destaca-se a partir deste propósito analítico a preeminência das experiências das pessoas com o mundo urbano que as cerca, uma ênfase analítica no "vivencial", no "sentimental", no "emocional", enfim, nos "sentidos" como veículos primordiais para a compreensão das relações humanas que na urbe se articulam e ganham uma densidade própria. Duarte (1999) indica que tal "império dos sentidos" na contemporaneidade é um conjunto de valores definidores do "dispositivo da sensibilidade" que rege a cultura ocidental moderna e com os quais, a nosso ver, Velho dialoga e os faz existir em arcabouços teórico-metodológicos bastante precisos. "Os sentidos estão tanto na raiz da razão como na da 'imaginação' ou das 'emoções' e 'paixões'. O fato cognitivo da 'experiência' se reduplica em fato emocional" (Duarte 1999:25).

Por meio dessa via analítica das sensibilidades, Velho observa o espaço urbano como lócus privilegiado onde selves experimentam-se e ao mesmo tempo descentram-se a partir de intensos e distintos processos. Com isso, formula um modo de conhecimento capaz de desestabilizar possíveis "coerências identitárias" (Velho 2011), algo que um projeto antropológico mais canônico da época ocasionalmente poderia vir a gerar. Os citadinos são assim descritos como repletos de vicissitudes e não como seres substanciais e coerentes: nem uma "tipologia" humana no contexto de uma "botânica urbana", muito menos "reinos" específicos a compor a "selva de pedra". Para isso, a antropologia de urbanas sensibilidades de Velho passeia por recorrentes linhas argumentativas encarnadas numa linguagem do sensível. Por exemplo, a constante afirmação de um "multipertencimento" dos sujeitos cosmopolitas (2010) ou da "fragmentação" de papéis e contextos que fazem com que tais identidades sejam dinâmicas e abertas à "mudança" (nomeadamente uma "metamorfose" em certas reflexões), claro, dentro de um "campo de possibilidades" que lhes 
impõe limites, mediações e conflitos (Velho 1994, 2001). Portanto, trata-se de subjetividades operadas com base em um jogo interativo e relacional que dá a elas uma diversidade de facetas e possibilidades de existência.

Neste projeto antropológico de Velho, o trabalho etnográfico se faz de "urbanas sensibilidades" justamente quando o pesquisador dá uma atenção especial às "ambiguidades" e aos "meios-tons" que conformam as experiências subjetivas nativas. "Em vez de âncoras, prefiro algo que remeta à memória, em permanente revisão, à socialização, às trajetórias e às escolhas contextualizadas" (Velho 2009a:15).

Gostaríamos de encerrar este ensaio apontando para como essa antropologia de urbanas sensibilidades começa a ser tecida já em Nobres e Anjos. A partir de um olhar mais distanciado de todo o material da obra, o que ali verificamos é uma etnografia das modalidades de hedonismos de jovens da elite urbana no início dos anos 1970. Velho faz uma densa descrição do "espírito", "clima" e "tom" das sensibilidades de juventudes contraculturais e suas vocações ao prazer por meio do recurso às drogas. Acreditamos que tal contraste entre hedonismos está sintetizado em dois conceitos pouco explorados pelo autor ao longo do livro, mas que gostaríamos aqui de realçar: o "hedonismo com camisa-de-força" (:63) para se referir aos nobres e o "hedonismo sem culpas" (:199), aos anjos. Não se trata, na verdade, da construção de dois universos distintos e antagônicos de busca pela satisfação, mas de apresentar os modos operativos de subjetivação pelos quais passam certos jovens ao utilizarem substâncias ilícitas, que ora se afastam, ora se aproximam em variados aspectos emocionais.

As expressões sensíveis da "camisa-de-força" e do "sem culpas" apontam explicitamente para tensões subjetivas que o consumo de drogas provoca em seus usuários enquanto recursos de prazer e meios de sensibilização do corpo no espaço urbano. Duarte (1999:28) defende que o uso de estimulantes na contemporaneidade gera constantemente nos sujeitos uma experiência subjetiva um tanto polarizada, pendular, entre a maximização da vida, ou seja, um investimento no longo prazo e na duração, e a otimização do corpo, que é a aposta no curto prazo, na intensidade, através da concentração do prazer. A "camisa-de-força" dos jovens adultos investigados por Velho alude justamente a uma sutil percepção etnográfica em torno das ambiguidades e das ponderações subjetivas que seus interlocutores fazem quando diante dos riscos gerados pela intensidade dos prazeres imediatos dos "tóxicos" e o contraste com seus planos de vida. A projeção constante de futuro em torno do que desejam ser e do que pretendem ter/ consumir torna os nobres constantemente "ansiosos" (Velho 1998:64), com idas e vindas nos tipos e nas quantidades de drogas a serem consumidas ao longo dos tempos. 
Se a eventual destruição da pessoa é um desafio ao grupo, por conta dos "excessos" das substâncias entorpecentes, por outro lado, a psicanálise emerge como um investimento na continuidade extensiva do corpo. Logo, a valorização da "mudança", do se "transformar" cria um tipo específico de urbana sensibilidade, de laços emocionais ambíguos entre os sujeitos, de forte contenção dos sentimentos e afetos na esfera pública, algo que se projeta inclusive numa sociabilidade conflitiva entre eles, às vezes explosiva e violenta. Portanto, o vanguardismo combinado com o aristocracismo gera um hedonismo dúbio, às vezes vacilante, de "meios-tons", "em que uma ideologia de liberação individual aparece misturada a fortes aspirações de bem-estar material e consumo sofisticado" (:198). Os nobres ora apostam numa continuidade máxima da vida por meio de "ansiedades" que freiam seus ímpetos, ora investem na otimização dos prazeres sensíveis através do recurso lúdico às drogas. As descrições do autor sobre as "viagens" ocasionadas pelo consumo de ácido são emblemáticas desses contrastes subjetivos entre a fruição sensorial e a "ansiedade" diante dos perigos de perda do controle e término de projetos e carreiras pessoais (:51).

Por sua vez, a comparação com o "hedonismo sem culpa" dos anjos permite a Velho matizar as sensibilidades contraculturais. A marca da transgressão se faz nesse grupo baseada na filosofia do live and let live (:199): desfrutar as "coisas boas" da vida, organizar-se de modo a realizar objetivamente seus desejos e prazeres mais imediatos. Eles não apresentariam as "ansiedades" típicas dos nobres, o que os torna muito mais intensivos em vista da excitação descompromissada dos sentidos, menos vacilantes na entrega corpórea aos prazeres, vide a "sexualização" que o autor diz ser uma marca do grupo. Além disso, os anjos não criariam polêmicas propriamente ditas entre eles, procurando realizar seus valores de vida com o mínimo de desgaste possível no âmbito das sociabilidades entre os pares. Não demonstrariam nenhum interesse mais contínuo ou persistente pela sociedade como um todo, o país e o mundo, apenas o de usufruir intensamente dos próximos, estar sempre com eles ao redor, num gregarismo de bandos.

É importante destacar o quanto Velho também busca apontar para os limites desse hedonismo, realçando que tal descompromisso generalizado, "sem culpas", não afasta os jovens das marcas de distinção de classe e raça (como vimos anteriormente), percebidas também nas disputas em torno do culto à beleza, nas competições esportivas e no consumo de produtos importados, "de marca". É claro que o hedonismo do "deixar viver" aproximaria os anjos muito mais da imagem estereótipo do "desbunde" contracultural, mas Velho procura demonstrar que esse imaginário, devido a fortes marcas de classe, é explicitamente negado por seus interlocutores ${ }^{17}$. 
O grupo estudado [anjos] não é totalmente imune a ideias sobre a Era de Aquário, época livre, sem repressões, de plena felicidade. No entanto, entre os grupos que consomem tóxicos, há vários outros que encarnam melhor, mais vigorosamente essa expectativa. A razão disso parece-me ser que, fundamentalmente, os jovens em pauta não estão à procura de uma Terra Prometida ou de uma Idade de Ouro, na medida em que a Ipanema na década de 70 para eles oferece boas possibilidades de uma vida bem vivida, de acordo com seus valores (:180).

A "ruptura" (social) e a "mudança" (individual, que leva o sujeito a outra existência) são valores que movimentam essas pessoas e orientam suas condutas pelo Rio de Janeiro dos anos 1970. Na antropologia de urbanas sensibilidades presente em Nobres e Anjos, biografias e trajetórias são colocadas em contraste, a fim de suscitar a reflexão sobre diferentes experiências subjetivas pelas quais passavam os jovens, mas que poderiam ser alocadas em um mesmo grupo caso se privilegiasse uma visão mais distanciada, objetificadora de "tipos" urbanos. Os sentidos de suas existências, seus projetos, memórias, desejos e vontades são a todo instante explicitados e tensionados, amplamente marcados por uma descrição etnográfica que ressalta a todo momento as variações de suas tonalidades. Ao apontar para mudanças e transformações subjetivas, Velho estimula também um olhar para a conjugação que fazem as pessoas de experiências sensíveis que poderiam ser vistas como contraditórias (as drogas e a psicanálise, por exemplo). Por meio desse movimento, Velho deixa de negligenciar assim a "vida emocional", "afetiva", dos grupos que estudava, algo que ele acreditava ser recorrente nas ciências sociais dedicadas ao urbano nos anos 1970: "Mas, ao fazer a etnografia dessas situações, o que ficou patente para mim é que, além da lógica que possa sustentar esses mapas, era importante captar certos aspectos afetivos da vida do grupo que normalmente são pouco considerados nesse tipo de trabalho" (:61).

Logo, quarenta e cinco anos depois, Nobres e Anjos permanece uma obra atual, com particular pujança para pensar as dinâmicas pouco estáveis da vida urbana e "familiar" para muitos de nós. A obra mantém o fôlego epistemológico como recurso importante para compreender as dinâmicas e as vicissitudes do comportamento desviante, assim como por ser fonte de inspiração devido à sua articulação com os estudos hoje cunhados de "interseccionalidades" e/ou "marcadores sociais da diferença". Portanto, é interessante perceber como a união de categorias analíticas como "antropologia das emoções" e "antropologia urbana", que hoje aparecem com bastante recorrência e que para muitos pesquisadores é quase uma redundância, tiveram suas mudas plantadas na obra seminal de Velho que aqui buscamos analisar. 
Recebido em: 27 de julho de 2019

Aprovado em: 31 de janeiro de 2020.

Raphael Bispo

Professor Adjunto do Departamento de Ciências Sociais e do Programa de Pós-Graduação em Ciências Sociais (PPGCSO) da Universidade Federal de Juiz de Fora (UFJF), atuando como Editor-Responsável da Revista Teoria e Cultura e Coordenador do FEGS - Grupo de Pesquisa em Família, Emoções, Gênero e Sexualidade (Diretório CNPq). Mestre e Doutor em Antropologia Social pelo Museu Nacional/UFRJ. Bacharel em Ciências Sociais pela UERJ e em Comunicação Social - Jornalismo pela UFRJ. Tem experiência na área de Antropologia Urbana, cobrindo temáticas ligadas aos estudos de gênero, da sexualidade, das emoções, da juventude, do envelhecimento, das religiosidades e da comunicação de massa. Suas pesquisas analisam as chamadas culturas de massas ou midiáticas e suas interfaces com marcadores sociais da diferença como a idade, o gênero, a sexualidade e a religião. Dedica-se também ao estudo das emoções pelo prisma das ciências sociais, enfocando particularmente as dinâmicas e os processos do sofrimento. Atualmente desenvolve investigações sobre: 1. gênero, emoções e religiosidades pentecostais, atentando especificamente para a prática testemunhal na conversão religiosa de artistas populares brasileiros e 2. histórias da antropologia urbana no Brasil a partir da trajetória de Gilberto Velho.

https://orcid.org/0000-0003-2703-9397

E-mail: raphaelbispo83@gmail.com

Oswaldo Zampiroli

É mestre e doutorando em Antropologia Social no Programa de Pós-Graduação em Antropologia Social (PPGAS) pelo Museu Nacional-UFRJ. Atualmente é pesquisador associado do Núcleo de Pesquisa em Família, Emoções, Gênero e Sexualidade (FEGS) da Universidade Federal do Rio de Janeiro, e também é pesquisador do Núcleo de Estudos em Corpos, Gênero e Sexualidade (NuSEX) do PPGAS-MN-UFRJ. Tem interesses de pesquisa nas grandes áreas de família, geração, emoções, gênero e sexualidade.

https://orcid.org/0000-0002-3985-237X

E-mail: owl.zampiroli@gmail.com 


\section{Nota}

1 Além de textos da autoria de Velho (artigos, memoriais, obituários, apresentações de livro etc.), este ensaio faz uso de trabalhos de outros antropólogos capazes de situar historicamente tanto Nobres e Anjos quanto este autor. Destacamos que as memórias de Velho emitidas em entrevistas e conferências (impressas ou em formatos audiovisuais) foram aqui também importantes. Cabe destacar que este ensaio é fruto de um projeto de pesquisa mais amplo, intitulado "Histórias da Antropologia Urbana no Brasil: caminhos do pensamento antropológico ao encontro da trajetória de Gilberto Velho" e que conta com o apoio da Pró-Reitoria de Pós-Graduação e Pesquisa da Universidade Federal de Juiz de Fora (UFJF). Por fim, agradecemos também imensamente às sugestões dos/as pareceristas de Mana que em muito colaboraram para os debates que aqui faremos ao longo do ensaio.

2 Mandrix é um composto que foi comercializado, durante os anos 1970, como comprimido para dormir. Tem efeito sedativo e hipnótico. Ficou popularmente conhecido, pelo seu uso recreativo, através da biografia da escritora alemã Christiane F. Roqueiros da época como Rita Lee e Raul Seixas confessaram terem sido "dependentes" deste tipo de remédio.

3 O autor diz ter tido dificuldades de interação com esse segmento juvenil, por serem eles bem mais novos e nem um pouco afeitos ao estilo de vida "nobre" que ele desempenhava sendo um "intelectual de livro publicado" (Velho 1998:184). Assim, fez uso de várias estratégias para estar com o grupo, como o auxílio de seu assistente de pesquisa, Eduardo Viveiros de Castro, seis anos mais jovem do que ele e que conhecia vários frequentadores da lanchonete. Essa discrepância na inserção no campo faz-se explícita na disposição desigual dos dados sobre os grupos na obra. Enquanto para os nobres são dedicados três capítulos, o estilo de vida dos anjos é apresentado aos leitores em um único. Sendo um trabalho de campo mais baseado numa observação direta da lanchonete, às vezes da praia, mas sem um conhecimento detalhado do estilo de vida dos anjos tal como o dos nobres, isso em nada impede a construção das comparações tecidas por Velho na tese. Isto porque essas dificuldades da pesquisa são explicitadas e servem como mote a fim de melhor compreender o estilo de vida daqueles que negam a ele uma maior intimidade.

4 Publicado em 1980, o livro O Desafio da Cidade é uma coletânea organizada por Velho cuja proposta era, talvez, aquilo que mais colocava à prova a geração pioneira de pesquisadores do urbano: os "problemas metodológicos relacionados a distanciamento, objetividade, familiaridade" (Velho 1980:13) em torno das especificidades de se fazer antropologia na cidade. Haveria uma particularidade nesses contextos e a missão era pensar as metodologias adequadas e os limites da aplicabilidade das que foram consolidadas pelas teorias clássicas dedicadas aos estudos dos povos tradicionais. Não é à toa que outros importantes textos com o mesmo mote foram lançados justamente nesse período, o que nos confirma a missão inicial desses autores fundadores não só de "tatear" um campo ainda incipiente, como também de buscar legitimidade científica entre os pares através da delimitação precisa de "métodos". Destaco também o clássico artigo "Observando o Familiar", do próprio Velho 
(1978), e a coletânea A aventura antropológica: teoria e pesquisa (1986), organizada por Ruth Cardoso, como obras-sínteses desse momento marcante da antropologia urbana em torno das buscas metodológicas.

5 Cabe aqui um comentário sobre o doutorado de Velho na USP, instituição que, no início dos anos 1970, possuía linhagens teóricas muito bem delimitadas no contexto das ciências sociais. Velho compôs uma das primeiras gerações de intelectuais que não precisaram sair do país para obter sua titulação. Não havendo ainda o doutoramento no Museu Nacional, onde obteve seu mestrado, foi apresentado por Roberto Cardoso de Oliveira, então coordenador do PPGAS, a Ruth Cardoso, da USP, tornando-se seu segundo orientando (Magnani 2012:60). O curso de doutorado não exigiu sua presença física em São Paulo, apenas para algumas palestras, já que havia concluído créditos tanto por meio do mestrado quanto de uma especialização nos EUA. Acredito ser importante destacar esse "distanciamento" de Velho da cena intelectual paulistana visto que sua tese de doutorado dialoga de maneira bastante restrita com os arcabouços teórico-metodológicos difundidos na USP daquela época, inclusive com os de sua orientadora, como veremos adiante. Em memórias recentes, Velho considerava Cardoso importante "interlocutora" e "amiga". Muito de sua criatividade na tese teria a ver com a liberdade intelectual garantida a ele por seu modo de orientar. "A Ruth era, sobretudo, a expressão de um ecletismo saudável. Não tinha preconceitos intelectuais". Mais informações sobre essa relação em Velho (2008a, 2008c, 2009b).

6 Precisamente, Velho credita o refinamento de seu pensamento ao curso "Etnografia dos hospitais psiquiátricos e prisões" que fez no Texas com o professor "semialternativo" Ira Buchler, visto que teria não só aprofundado ali os estudos sobre Erving Goffman, mas também conhecido o livro Outsiders de Becker, talvez a obra mais importante para a confecção de Nobres e Anjos (Velho 2008c; Vianna, Kuschnir \& Castro 2013:15).

7 Anthony Leeds era à época professor da Universidade do Texas. Antropólogo formado por Columbia, onde concluiu seu doutorado em 1957 sob a cultura de plantation baiana, caminhou pelas linhas teóricas dos chamados estudos de comunidade. Ele veio dar aulas nos primeiros anos do PPGAS do Museu através do convênio vigente com a Fundação Ford. É dele o primeiro curso de "Antropologia Urbana" no Brasil, de 1969, visto seu interesse posterior por favelas e modelos de habitação. Destacamos aqui que Leeds já denominava sua abordagem como uma "antropologia urbana", algo que Velho levaria adiante depois de seu retorno dos EUA. Ele foi seu aluno no curso e fez como trabalho final da disciplina, junto com Yvone Maggie, um esboço etnográfico daquilo que viria a ser seu tema de mestrado, os conjugados de Copacabana. Para mais informações sobre esse momento em particular da trajetória de Velho, ver Velho (2011); Velho \& Maggie (2013); O'Donnell (2013). A obra Sociologia do Brasil Urbano de Anthony e Elizabeth Leeds é uma forma de conhecer as ideias desses autores. Uma primeira versão circulou em 1978 pela editora Zahar, graças às iniciativas de Velho, estando hoje esgotada. Uma nova edição, revista e ampliada, foi disponibilizada atualmente no meio acadêmico (Leeds, A. \& Ledds, E. 2015). 
8 Shelton Davis era um etnólogo norte-americano e foi o orientador formal da dissertação de Velho. Ele também atuou como professor nos anos iniciais do PPGAS por conta da parceria com a Fundação Ford.

9 Fundada em 1933, a ELSP é resultado das primeiras iniciativas de institucionalização das ciências sociais no Brasil. Com forte influência de teóricos norte-americanos, particularmente da Escola de Chicago, recebeu em seus quadros pesquisadores estrangeiros como Donald Pierson (que por lá ficou cerca de 20 anos, inclusive coordenando a instituição), Herbert Blumer e mesmo Robert Park. Essa cena intelectual desencadeou os estudos de comunidade, os quais instituíram pesquisas antropológicas restritas espacialmente, descritivas de "localidades tradicionais" e tendo o funcionalismo como norte teórico, além dos modelos do continuum folk-urbano de Chicago. Essa tradição foi duramente atacada nos anos 1960 e 1970 por ser "acrítica", "culturalista", pouco atenta aos "conflitos sociais" e às "lutas de classe", particularmente pela sociologia marxista que ganhava peso na USP. Mais detalhes sobre a ELSP em Mendoza (2005); Magnani (2012) e Dutra e Ribeiro (2013).

10 Magnani (2012) afirma que, nas ciências sociais da USP dos anos 1960, eram os etnólogos "culturalistas" Emilio Willems e Egon Schaden - formados nos estudos de comunidade e em intensos diálogos com a ELSP - os responsáveis pela condução das pesquisas antropológicas na universidade. Tanto Durham quanto Cardoso (esta última até então orientanda de Schaden) mudaram para o departamento de ciência política em razão de divergências teórico-metodológicas com esses professores. Cardoso viria a ser orientada por Florestan Fernandes logo em seguida, quando este ganhava projeção nacional ao fazer uma "sociologia crítica" das relações raciais no Brasil, tendo como base uma leitura marxista do fenômeno. "Ante esse quadro, Ruth e Eunice inauguraram uma via própria, sem abandonar a Antropologia e seu enfoque, mas também sem se perder em particularismos; incorporam uma perspectiva em que a mudança e os conflitos são pensados em suas determinações estruturais, mas que levam em conta também a ação dos atores sociais diretamente envolvidos, com desdobramentos políticos" (Magnani 2012:51-52).

11 Se quisermos pensar em "linhagens" da antropologia urbana, tal como formulou Magnani (2012), cabe destacar que o ano de 1973 viu chegar às livrarias tanto A utopia urbana, de Velho, quanto A caminho da Cidade, de Durham. Duas influentes, porém, distintas maneiras de refletir sobre as urbanidades na antropologia da década de 1970. Reconhece Velho: "[Ruth Cardoso] Inaugurou, na Universidade de São Paulo - USP, juntamente com a doutora Eunice Durham, o campo da antropologia urbana, focalizando diversos temas" (Velho 2008a:271).

12 Essa ideia de "contexto" em muito se liga à análise que Durham faz, em meados dos anos 1980, acerca do que se tratava fazer uma antropologia das "populações urbanas" naquele momento. Apoiando-se na recorrente dicotomia na ou da cidade, a pesquisadora defendia que, no Brasil, o urbano em si mesmo não chegou a ser uma questão central, sendo ele um mero "cenário", algo mais amplo que circunscreve de forma direta os processos político-culturais analisados, como a imigração, a favelização, a mobilidade etc. Faríamos, portanto, uma antropologia na cidade, preponderantemente (Durham 1986). 
13 Acreditamos ser sempre problemática a análise de um complexo campo de conhecimento quando buscamos o "primeiro" a ter realizado determinado feito, visto que isto apaga por completo as continuidades e as rupturas da formação do pensamento em específicas trajetórias intelectuais, além de observar de maneira bastante linear, e não caleidoscópica, uma determinada área de estudos.

14 Cabe destacar a ausência em Nobres e Anjos das típicas interpretações das camadas médias feitas por Velho tendo como base analítica a hegemonia da ideologia do individualismo nesses segmentos que, constata Duarte (2012a: 6), consistia em interpretações próprias que combinavam Louis Dumont e Georg Simmel. Isto se tornará mais explícito na trajetória intelectual de Velho em textos dos anos 1980, como Individualismo e Cultura (1981). Parece que ainda, nesse momento, a classe social é pensada por Velho primordialmente por meio dos processos sociológicos de distinção e estratificação. Talvez seja esta a maior influência em sua tese das teorias tão em voga na USP daquele período e que ele rapidamente substituirá por outros fios interpretativos sobre as classes médias, menos "sociológicos", com o passar dos anos.

15 É com orgulho que Velho diz: "O que eu acho que aconteceu conosco aqui é que o Brasil, e nesse ponto eu não sou nada modesto, o que nós chamamos de antropologia urbana, o lugar em que isso mais se desenvolveu foi no Brasil. É no Brasil! Então, o que eu acho que aconteceu aqui foi uma síntese, que não é homogênea, múltiplas leituras, um conjunto de tradições que se encontram. Eu tenho muita satisfação por isso" (Velho 2006).

16 Complementa Duarte sobre tal epistemologia: “Não se tratava, para Gilberto, de aprofundar a desconfiança em relação aos fundamentos ontológicos das certezas da cultura ocidental, mas sim de mapear os meandros da significação vivencial concreta; recolher, interpretar e retratar as minúcias das existências e experiências palpáveis emergentes na confluência das 'redes' de significado e das 'tramas' interativas. Nesse sentido era uma fenomenologia inseparável de uma 'sociologia' - no sentido metodológico a que me referi antes. Os comportamentos são estrategicamente privilegiados, mas a carnatura morfológica em que vicejam é constantemente observada, levada em conta, perquirida" (2012b:6)

17 Uma forma de situar historicamente esse consumo "transgressivo" e "escapista" de "drogas" são os dados presentes em algumas pesquisas recentes sobre os usos atuais dessas substâncias, particularmente o ecstasy: consumo pragmático, numa visão farmacológica de si, visando a um bem-estar por meio de um "cálculo" e uma "competência" no uso dessas substâncias, característico das sociedades de controle contemporâneas. Mais detalhes para esse contraste entre a contemporaneidade e o período contracultural em Almeida e Eugênio (2007) e Almeida e Bispo (2018). 


\section{Referências bibliográficas}

ALMEIDA, Maria Isabel Mendes de \& EUGÊNIO, Fernanda. 2007. "Paisagens existenciais e alquimias pragmáticas: uma reflexão comparativa do recurso às 'drogas' no contexto da contracultura e nas cenas eletrônicas contemporâneas". In: M.I.M. de Almeida e S.C. Naves (orgs.), "Por que não?": rupturas e continuidades da contracultura. Rio de Janeiro: Sete Letras.

ALMEIDA, Maria Isabel Mendes de \& BISPO, Raphael. 2018. "Desmobilizações juvenis e a reimaginação da resistência na contemporaneidade em contraste com o período contracultural". Teoria e Cultura, v. 13, n. 1:215-231.

BECKER, Howard S. 1996. A Escola de Chicago. Mana, v. 2, n. 2:177-188.

BENJAMIN, Walter. 1995. Obras Escolhidas III. Charles Baudelaire: um lírico no auge do capitalismo. São Paulo: Brasiliense.

BOMENY, Helena. 2015. "O 'fazedor de redes': a dimensão institucional da trajetória de Gilberto Velho". In: Celso Castro \& Graça Índias Cordeiro (orgs.), Mundos em mediação: ensaios ao encontro de Gilberto Velho. Rio de Janeiro: Editora FGV.

CARDOSO, Ruth (org.). 1986. A aventura antropológica: teoria e pesquisa. São Paulo: Paz e Terra. . 2011a [1959]. "O papel das associações juvenis na aculturação dos japoneses". In: Teresa Pires do Rio Caldeira (org.), Ruth Cardoso: obra reunida. São Paulo: Mameluco. . 2011b [1978]. "Sociedade e poder: as representações dos favelados de São Paulo". In: Teresa Pires do Rio Caldeira (org.), Ruth Cardoso: obra reunida. São Paulo: Mameluco.
DUARTE, Luiz Fernando Dias. 1999. "O império dos sentidos: sensibilidade, sensualidade e sexualidade na cultura ocidental moderna". In: Maria Luiza Heilborn (org.), Sexualidade: o olhar das ciências sociais. Rio de Janeiro: Jorge Zahar. . 2012a. "Gilberto Velho (19452012): um virtuoso no burburinho das cidades". Revista Brasileira de Ciências Sociais, v. 27, n. 79:5-8.

. 2012b. "Fenomenologia e singularidade: o pensamento de Gilberto Velho". Academia Brasileira de Ciências. Homenagem a Gilberto Velho. Disponível em: < https://www.academia.edu/8966959/ Fenomenologia_e_singularidade_o_ pensamento_de_Gilberto_Velho > Acesso em 14/03/2019.

DURHAM, Eunice Ribeiro. 1984 [1973]. A caminho da cidade. São Paulo: Perspectiva. . 1986. "A pesquisa antropológica com populações urbanas: problemas e perspectivas". In: Ruth Cardoso (org.), A aventura antropológica: teoria e pesquisa. São Paulo: Paz e Terra.

. 2004 [1973]. "Imigrantes italianos". In: Eunice Ribeiro Durham, A dinâmica da cultura. São Paulo: Cosac Naify.

DUTRA, Rogéria Campos \& RIBEIRO, Nádia Oliveira. 2013. "A Antropologia Urbana no Brasil". Teoria e Cultura, v. 8, n. 1:127-138.

CORDEIRO, Graça Índias. 2015. "Do próximo ao complexo: o desafio antropológico da cidade". In: Celso Castro \& Graça Índias Cordeiro (orgs.), Mundos em mediação: ensaios ao encontro de Gilberto Velho. Rio de Janeiro: Editora FGV. 
LEEDS, Anthony \& LEEDS, Elizabeth. 2015. A sociologia do Brasil urbano. Rio de Janeiro: Editora Fiocruz.

MAGNANI, José Guilherme Cantor. 1996. "Quando o campo é a cidade: fazendo antropologia na metrópole". In: José Guilherme Cantor Magnani \& Lillian de Lucca Torres (orgs.), Na Metrópole: textos de antropologia urbana. São Paulo: EdUSP/ Fapesp.

. 2012. Da periferia ao centro: trajetórias de pesquisa em antropologia urbana. São Paulo: Editora Terceiro Nome.

MENDOZA, Edgar. 2005. "Donald Pierson e a Escola Sociológica de Chicago no Brasil: os estudos urbanos na cidade de São Paulo (19351950)". Sociologias, n. 14:440-470.

O'DONNELL, Júlia. 2013. "Caminhos de uma antropologia urbana: trajetória e projeto nos primeiros escritos de Gilberto Velho". Anuário Antropológico, v. 38, n. 2:37-51.

OLIVEN, Ruben George. 1980. "Por uma Antropologia em cidades brasileiras". In: Gilberto Velho (org.), O desafio da cidade: novas perspectivas da antropologia brasileira. Rio de Janeiro: Campus.

PEIRANO, Mariza. 2006. A teoria vivida e outros ensaios de antropologia. Rio de Janeiro: Jorge Zahar Editor. . 2012. "Gilberto". Academia Brasileira de Ciências. Homenagem a Gilberto Velho. Disponível em: $<$ http://www.marizapeirano.com. br/diversos/gilberto_velho.htm >. Acesso em 14/03/2019.

SIMMEL, Georg. 1976. "A metrópole e a vida mental". In: Otávio Velho (org.), O fenômeno urbano. Rio de Janeiro: Zahar Editores.

VELHO, Gilberto. 1973. A utopia urbana: um estudo de antropologia social. Rio de Janeiro: Jorge Zahar.
. 1978. "Observando familiar". In: Edson de Oliveira Nunes (org.), A aventura sociológica. Rio de Janeiro: Zahar Editores.

. 1980. "O antropólogo pesquisando em sua cidade: sobre conhecimento e heresia". In: Gilberto Velho (org.), O desafio da cidade: novas perspectivas da antropologia brasileira. Rio de Janeiro: Editora Campus. . 1981. Individualismo e Cultura: notas para uma antropologia da sociedade contemporânea. Rio de Janeiro: Jorge Zahar Editor. . 1986. Subjetividade e Sociedade: uma experiência de geração. Rio de Janeiro: Jorge Zahar Editor.

- 1994. Projeto e Metamorfose: antropologia das sociedades complexas. Rio de Janeiro: Jorge Zahar Editor. . 1998. Nobres e Anjos: um estudo de tóxicos e hierarquia. Rio de Janeiro: FGV. . 2001. "Biografia, trajetória e mediação". In: Gilberto Velho \& Karina Kuschnir (orgs.), Mediação, cultura e política. Rio de Janeiro: Aeroplano. . 2002. "Becker, Goffman e a Antropologia no Brasil". Ilha, v. 4, n. 1:5-16.

. 2005. "Reflexões sobre a Escola de Chicago". In: Licia do Prado Valladares (org.), A Escola de Chicago: impacto de uma tradição no Brasil e na França. Belo Horizonte e Rio de Janeiro: UFMG/ Iuperj. . 2008a. "Ruth Corrêa Leite Cardoso". Dados, v. 51, n. 2:271-274. . 2008b. "Goffman, mal-entendidos e riscos interacionais". Revista Brasileira de Ciências Sociais, v. 23, n. 68:145-147.

. 2009a. "Antropologia Urbana: encontro de tradições e novas perspectivas". Sociologia, problemas e práticas, n. 59:11-18. 
. 2010. "Metrópole, cosmopolitismo e mediação". Horizontes Antropológicos, n. 33:15-23.

. 2011. "Antropologia Urbana: interdisciplinaridade e fronteiras do conhecimento". Mana, n. 17, v. 1:161-185.

. 2012. "Memorial". Mana, v. 18, n. 1:173-212.

VELHO, Gilberto \& MAGGIE, Yvonne. 2013. "O Barata Ribeiro 200 com pós-escrito de Yvonne Maggie e comentários de Anthony Leeds". Anuário Antropológico, v. 38, n. 2:19-36.

\section{Videografia}

VELHO, Gilberto. 2006. Narradores urbanos, antropologia urbana e etnografia nas cidades brasileiras: Gilberto Velho. (18min). Direção: Ana Luiza Carvalho da Rocha e Cornelia Eckert. Produção: Banco de Imagens e Efeitos Visuais/BIEV/ UFRGS. Disponível em: <https:// vimeo.com/50699082>. Acesso em 25/02/2019.

VELHO, Gilberto. 2008c. Conversa com o autor: Gilberto Velho (UFRJ). (29min). Produção: $32^{\circ}$ Encontro
VIANNA, Hermano; KUSCHNIR, Karina \& CASTRO, Celso. 2013. "Apresentação". In: Gilberto Velho, Um antropólogo na cidade: ensaios de antropologia urbana. Rio de Janeiro: Zahar.

VIVEIROS DE CASTRO, Eduardo. 1999. "Etnologia Brasileira". In: Sergio Miceli (org.), O que ler na ciência social brasileira 1970-1995. São Paulo: Editora Sumaré.

Anual da Associação Nacional de Pós-Graduação e Pesquisa em Ciências Sociais (ANPOCS). Disponível em: <https://www.youtube.com/ watch?v= AlDrm-_DK3s\&t=1s $>$. Acesso em 14/03/2019.

VELHO, Gilberto. 2009b. Entrevista com Gilberto Velho. (1h51min). Produção: Projeto Memória das ciências sociais no Brasil/ CPDOC/FGV. Disponível em: <https://www.youtube.com/ watch $? \mathrm{v}=7 \mathrm{rtlGIL67tw}>$. Acesso em 26/02/2019. 


\section{NOBRES E ANJOS, 45 ANOS DEPOIS: GILBERTO VELHO E A ANTROPOLOGIA DE URBANAS SENSIBILIDADES}

\begin{abstract}
Resumo
Nobres e Anjos: um estudo de tóxicos e hierarquia foi a tese de doutoramento de Gilberto Velho (1945-2012), defendida em 1975 na Universidade de São Paulo, mas publicada apenas no ano de 1998. Este ensaio procura estimular um duplo movimento ao retomar uma obra que há quarenta e cinco anos serve de inspiração a inúmeros antropólogos: num primeiro plano, relembrar e situar as vivências de juventudes que encontraram suas formas de estar na cidade associadas às satisfações subjetivas geradas pelo uso de drogas nas franjas de um regime autoritário. Por outro lado, refletir sobre a maneira pela qual esse campo plural da antropologia urbana tem se constituído na prática e teoricamente entre nós, considerando a obra de Velho como referência central para a afirmação de um modo específico e original de estudo das cidades nas teorias sociais brasileiras - o que nomearemos aqui de antropologia de urbanas sensibilidades.
\end{abstract}

Palavras-chave: Gilberto Velho, Antropologia urbana, Juventudes, Drogas, Emoções.

\section{NOBRES E ANJOS, 45 YEARS LATER: GILBERTO VELHO AND THE ANTHROPOLOGY OF URBAN SENSIBILITIES}

\begin{abstract}
Nobres e Anjos: um estudo de tóxicos e hierarquia (Nobles and Angels: a study of toxicology and hierarchy) was the doctoral thesis of Gilberto Velho (19452012), defended in 1975 at the University of São Paulo, but published only in 1998. This article invites a double movement by returning to a book that, for fortyfive years, has remained an inspiration for countless anthropologists: first, we remember and situate the experiences of youths who found their ways of being in the city associated with the subjective satisfactions generated by the use of drugs during an authoritarian regime. Second, we reflect on how this plural field of urban anthropology has been constituted in practice and in theory, considering the work of Velho as a central reference for the affirmation of a specific and original way of studying cities in Brazilian social theories - what we will here call an anthropology of urban sensibilities.
\end{abstract}

Keywords: Gilberto Velho, Urban anthropology, Youths, Drugs, Emotions. 


\title{
NOBRES E ANJOS, 45 AÑOS \\ DESPUÉS: GILBERTO VELHO \\ Y LA ANTROPOLOGÍA DE LAS \\ SENSIBILIDADES URBANAS
}

\begin{abstract}
Resumen
Nobres e Anjos: um estudo de tóxicos e hierarquia (Nobles y Ángeles: un estudio de toxicología y jerarquía) fue la tesis doctoral de Gilberto Velho (1945-2012), defendida en 1975 en la Universidad de São Paulo, pero publicada solo en 1998. Este ensayo trata de estimular un doble movimiento al reanudar un trabajo que durante cuarenta y cinco años ha sido la inspiración de innumerables antropólogos: en primer plano, recordar y situar las experiencias de las juventudes que encontraron sus formas de estar en la ciudad asociadas con las satisfacciones subjetivas generadas por el uso de drogas en un régimen autoritario. Por otro lado, analizar la forma en que este campo plural de antropología urbana se ha constituido práctica y teóricamente entre nosotros, considerando el trabajo de Velho como referencia central para la afirmación de una forma específica y original de estudiar las ciudades en las teorías sociales brasileñas - lo que aquí llamaremos la antropología de las sensibilidades urbanas.
\end{abstract}

Palabras clave: Gilberto Velho, Antropología urbana, Juventudes, Drogas, Emociones. 